\title{
Investigation on plasmid DNA separation under vacuum suction using cellulose generated and polyethersulfone ultra filters
}

\author{
Tengku Haziyamin Abdul Hamid", Azzmer Azzar Abdul Hamid \\ Department of Biotechnology, Kulliyyah of Science, International Islamic University Malaysia, Jalan Istana, 25200 Kuantan, Pahang, Malaysia.
}

\begin{tabular}{|c|c|}
\hline ARTICLE INFO & ABSTRACT \\
\hline Article history: & \multirow{11}{*}{$\begin{array}{l}\text { E. coli DH5 } \alpha \text { harbouring pET28a+ plasmid vector was lysed by alkaline lysis and the clarified plasmid solutions } \\
\text { were subjected to ultrafiltration experiments using two types of ultrafiltration membrane; i.e., cellulose } \\
\text { generated (Ultracel) and polyethersulfome PES (Biomax). Transmembrane pressures (TMP) through vacuum } \\
\text { suction of } 0.1 \text { to } 0.7 \text { bar were applied to the plasmid sample, and the corresponding flow rates and fluxes for } \\
\text { both filters were investigated. Even though, these two filters showed a slight different in the flux, a marked } \\
\text { different in DNA transmission were observed. DNA transmission were generally higher with cellulose generated } \\
\text { filters, whereby DNA transmission by Ultracel filter was at } 44.3,63.9,74.1,55.6 \text { and } 54.5 \% \text { at TMP of } 0.1,0.18 \text {, } \\
0.39,0.6 \text { and } 0.7 \text { bar, respectively. Meanwhile, for PES filters the DNA transmission was at } 22.3,38.1,39.1 \text {, } \\
38.0 \text { and } 37.5 \% \text { at TMP of } 0.1,0.3,0.4,0.6 \text { and } 0.7 \text { bar, respectively. With the cellulose generated filter, DNA } \\
\text { transmission reached an optimum }(\sim 0 \%) \text { at about } 0.6 \text { bar after which the transmission depleted at higher TMP } \\
\text { of } 0.7 \text { bar. Throughout all of the TMP, DNA transmissions observed were generally lower with PES filter. The } \\
\text { properties of the filter material could have contributed to the differences in DNA permeation. }\end{array}$} \\
\hline Received on: 06/03/2017 & \\
\hline Accepted on: 09/05/2017 & \\
\hline Available online: $30 / 07 / 2017$ & \\
\hline Key words: & \\
\hline Plasmid purification, & \\
\hline & \\
\hline & \\
\hline & \\
\hline & \\
\hline & \\
\hline
\end{tabular}

\section{INTRODUCTION}

The advent of biotechnology and molecular genetic in the $21^{\text {st }}$ century had resulted in many new disease causing genes being discovered. There are many genetic disorders in human arise from mutated and defective genes (Theodossiou et al., 1997). Interest in the use of viral and non-viral vector such as plasmids flourish in the area of gene therapy and vaccines (Ramamoorth and Narvekar, 2015; Yin et al., 2014). Moreover, the use of plasmid DNA in gene therapy is considered safer compared to viral vector (Guerrero-Germán et al., 2009). In order to meet this new demand, an efficient, cost effective large scale production and purification processes of producing pharmaceutical-grade plasmid DNA are needed (Ferreira et al., 2000). The plasmid is to be of high purity, free from other

\footnotetext{
* Corresponding Author

Tengku Haziyamin Abdul Hamid, Department of Biotechnology, Kulliyyah of Science, International Islamic University Malaysia, Jalan Istana, 25200 Kuantan, Pahang, Malaysia.

Email: haziyamin@iium.edu.my
}

cellular milieu such as proteins, genomic DNA, RNA and endotoxins. Moreover, since plasmid DNA is an informational molecule it will behave like a persistent pollutant unlike many other chemicals.

Even though chromatography is one of a common methods used in plasmid purification, it is expensive and has low plasmid binding capacity (Guerrero-Germán et al., 2009). Other than chromatography, filtration method is a valuable tools which can be used since it is relatively selective, cost effective and capable of purifying plasmid in single step operation (Arkhangelsky et al., 2011). Many studies have been done on the use of filtration to purify and separate plasmid from non-useful isoforms. Those area of prime concerns include various factors affecting filtration, and mechanism of how DNA molecules can penetrate and transfer through membranes (Ager et al., 2009; Latulippe and Zydney, 2011).

Due to its size and shape, the mechanism of plasmid transfer across membrane is not straight forward, unlike small molecules. Several factors have been characterised to determine the transition of DNA across filtration membrane. 
Some of these include plasmid size, stirring speed, membrane fouling, concentration polarization effect and the critical flux (Arkhangelsky et al., 2011). In depth study carried out by Latulippe and Zydney, demonstrated that other factors such ionic strength and membrane charge will also affect plasmid transition (Ager et al., 2009; Latulippe and Zydney, 2011). Membrane polymer type should be considered as one of an important parameter since the overall performance of a filtration process is determined by the filter material in combination with aforementioned factors. Studies have shown that hydrophobic membranes were more prone to fouling than did hydrophilic membranes (Kabsch-Korbutowicz et al., 1999). Therefore, during plasmid separation, hydrophobic membrane and hydrophilic membrane can result in different performances. The aim of this work is to investigate on how these two types of ultrafiltration membrane could perform in plasmid DNA purification. In addition, this work employed negative pressure source driven by vacuum suction, instead of using commonly used positive pressure in pumping sample across membrane. Plasmid DNA sample will be subjected to separation at different transmembrane pressures (TMP) and the effects of these on type of filters were characterised in the form of flow rates, flux and DNA transmission.

\section{MATERIALS AND METHODS}

\section{Plasmid DNA purification}

Plasmid pET28a+ of $5.369 \mathrm{kbp}$ in size was transformed into Escherichia coli strain DH5 $\alpha$ according to the manufacturer protocol (Novagen). The transformed cell was cultivated in $500 \mathrm{~mL}$ Luria Bertani (LB) medium with added antibiotic kanamycin $(0.5 \mathrm{mg} / \mathrm{mL})$. In $2.0 \mathrm{~L}$ shake flask following overnight incubation at $37^{\circ} \mathrm{C}$ with $1000 \mathrm{rpm}$ agitation, the cells were harvested. Following centrifugation at $1000 \mathrm{~g}$, the pellets were resuspended in $30 \mathrm{~mL}$ of $50 \mathrm{mM}$ glucose $10 \mathrm{mM}$ ethylene-diamine tetra-acetic acid (EDTA), $25 \mathrm{mMTris} / \mathrm{HCl}$, at $\mathrm{pH}$ 8.0. The cell disruption was performed according to method done by (Bimboim and Doly, 1979; Manzano et al., 2015), using alkaline lysis. Cellular lysis was carried out by adding $30 \mathrm{~mL}$ of ice-cold lysis solution containing $200 \mathrm{mM} \mathrm{NaOH}$ and $1 \%$ (w/v) sodium dodecyl sulfate solution (SDS). Then, $30 \mathrm{~mL}$ of ice-cold $3 \mathrm{M}$ potassium acetate ( $\mathrm{pH}$ 5.0) was added to gently precipitate unwanted material such as chromosomal DNA, RNA, proteins and other cellular debris. After a centrifugation at $10,000 \mathrm{~g}\left(25 \mathrm{~min}, 4^{\circ} \mathrm{C}\right)$, the precipitate was removed and concentrated $\mathrm{CaCl}_{2}$ was added to the supernatants to a final concentration of $0.4 \mathrm{M}$. Following a final centrifugation $10,000 \mathrm{~g}\left(25 \mathrm{~min}, 4^{\circ} \mathrm{C}\right)$, the supernatant was filtered $(0.45 \mu \mathrm{m}$ filter), pooled and kept for further analysis.

\section{Agarose gel electrophoresis}

Following plasmid transformation and alkaline lysis purification, the plasmid samples were checked by running $0.8 \%$ agarose gel electrophoresis. The electrophoresis was run at $100 \mathrm{~V}$ using TAE buffer containing $40 \mathrm{mM}$ Tris base, $20 \mathrm{mM}$ acetic acid and $1 \mathrm{mM}$ EDTA, $\mathrm{pH}$ 8.0, and stained with ethidium bromide
$(0.005 \mu \mathrm{g} / \mathrm{ml})$. The electrophoresed gel was visualised using geldocumentation system (Alpha Innotech Alpha Imager 2200).

\section{Filtration experiment}

Cross-flow filtrations were performed at room temperature using a unit of solvent clarification kit (Millipore) employing a vacuum suction mode as a source of transmembrane pressure (TMP). Two types of $44.5 \mathrm{~mm}$ diameter sterilising grade ultrafiltration disc of $100 \mathrm{kDa}$ nominal molecular weight limit (NMWL) were used (Merck Millipore) i.e., i) PBHK, Biomax polyethersulfone, and ii) PLHK, Ultracel regenerated cellulose. Pressure gauge was calibrated using buffer in order to attain a stable TMP such that a measurable filtrate volume could be collected at a rate of 0.5 to $6.0 \mathrm{mLmin}^{-1}$. The flux $\mathrm{J}$ was calculated from the following equation (1) (Kabsch-Korbutowicz et al., 1999):

$$
\mathrm{J}=\frac{\mathrm{V}}{\mathrm{tA}} \quad \ldots .(1)
$$

Where $\mathrm{J}$ is flux $\left(\mathrm{mLmin}^{-1} \mathrm{~cm}^{-2}\right) ; \mathrm{V}$ is the filtrate (permeate) volume collected $(\mathrm{mL}) ; \mathrm{A}$ is the effective area of filtration $\left(\mathrm{cm}^{2}\right)$ and $\mathrm{t}$ is the time of collection (min). Under operating suction, an appropriate volume of DNA containing lysis solutions were passed through the membrane and the time taken for 10 to $30 \mathrm{ml}$ of filtrate were recorded. Filter membrane was always replaced at each filtration cycle and routinely pre-wetted with buffer. Each of the filtration experiment was run in triplicates.

\section{DNA purity and concentration}

By using Nanodrop model 2000/2000c (Thermo Fisher Scientific, USA), the DNA concentrations in the feed and filtrate were determined at $260 \mathrm{~nm}$ (A260). DNA purity was measured as the relative $\mathrm{DNA}$ /protein content and expressed as the ratio of absorbance at $260 \mathrm{~nm}$ to that at $280 \mathrm{~nm}$ (A260/A280). In this work, all alkaline lysis samples used had an initial A260/A280 ratio between 1.6 and 1.9. The DNA transmission was expressed as a percentage $(\%)$ of the filtrate DNA concentration to that of feed DNA concentration.

\section{RESULTS AND DISCUSSIONS}

E. coli strain DH5 $\alpha$ cells was successfully transformed with $5.369 \mathrm{~kb}$ pET28a+ plasmid, and the transformed cells were cultivated and harvested for plasmid extraction using alkaline lysis solution. The result from agarose gel electrophoresis on the extracted plasmid was shown in Figure 1. The vector of size $5.369 \mathrm{kbp}$ was successfully transformed into this cell, and the transformed cell was used in the subsequent filtration experiment.

A plot in Figure 2a showed that there was a general increase in flow rate following an increase in TMP. In principle, flow rates will increase linearly with pressure for water or buffer with no retain solutes (Dosmar and Pinto, 2007). For Ultracel, slight deviation from linearity was observed at 0.2 bar and above TMP. Flow rate reached $7.0 \mathrm{~mL} \mathrm{~min}^{-1}$ at 0.6 bar but then slightly dropped to $6.8 \mathrm{mLmin}^{-1}$ at 0.7 bar. In contrast, with Biomax filter, the flow rate increased rather linearly at all TMPs. 
$\begin{array}{llllll}1 & 2 & 3 & 4 & 5 & M\end{array}$

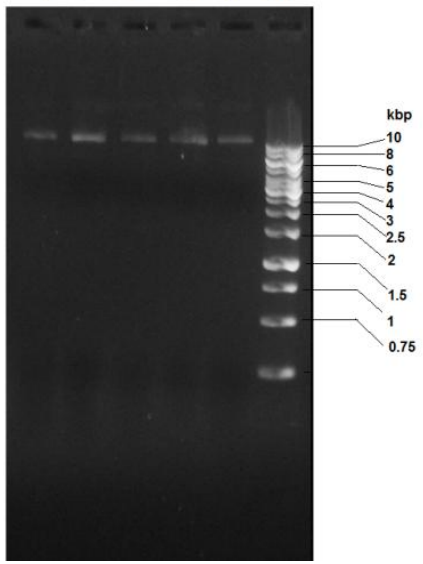

Fig. 1: Result from $0.8 \%$ agarose gel electrophoresis run on plasmid extraction samples. Lane 1, 2, 3, 4 and 5 are thereplicate samples containing concentrated DNA from alkaline lysis. The high molecular size bands (>10kb) in lane 1 to 5 represent a closed circular plasmid which has an actual size of $5.369 \mathrm{~kb}$ corresponding to pET28a+ vector. Lane M contained a standard $1 \mathrm{~kb}$ molecular weight marker (Fermentas, Lithuania).

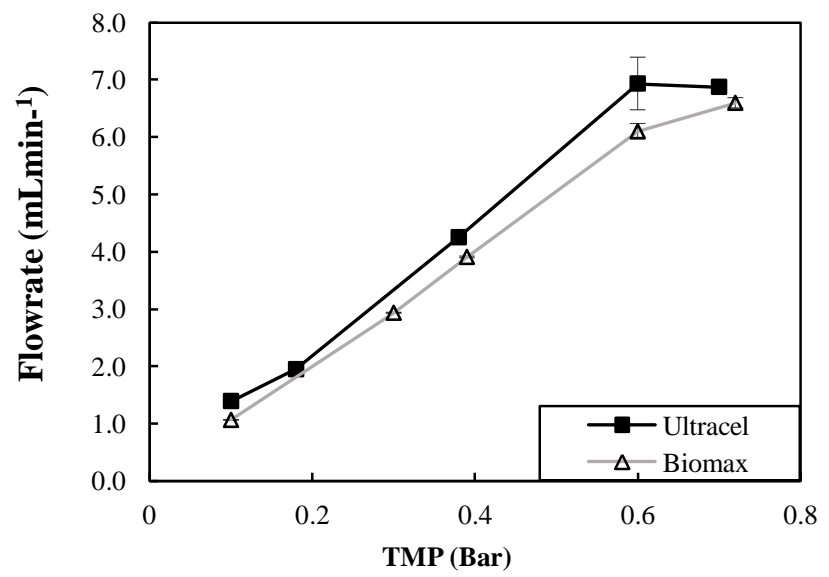

A

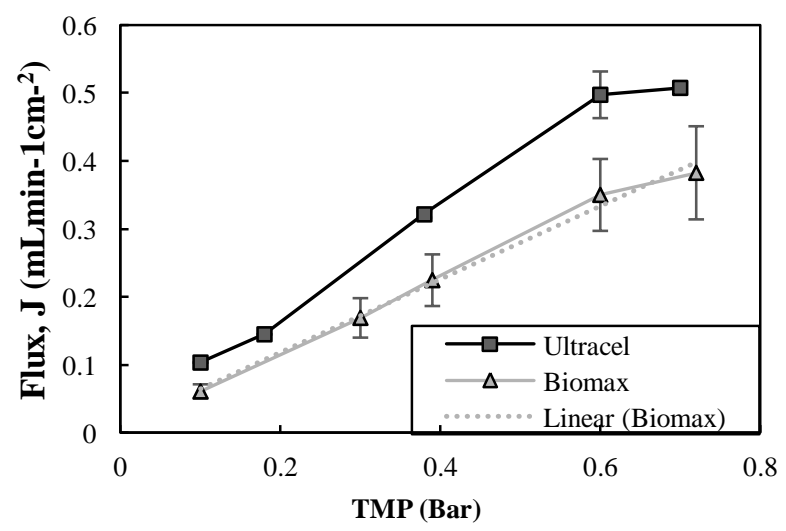

b

Fig. 2: The changes in flow rate (Figure 2a) and flux (Figure 2b) during ultrafiltration experiment run at different transmembrane pressures or TMP using Ultracel and Biomax filters.

As shown in Figure 2b, greater fluxes were generally observed with Ultracel compared Biomax filter, a trend similar to flow rates. TMP and flux can be related by Darcy law (Manzano et al., 2015; Meireles et al., 2003). The membrane fluxes at varying
TMPs can be characterised by different phases (Claudia Muro et al., 2012). First phase is referred to as 'subcritical flux' characterised by a linear change in flux with TMP. Further increase in TMP will result in 'limiting flux', a region in which any increase in TMP will not affect flux due mainly to the membrane fouling. In the same figure, a deviation from linearity was obvious with Ultracel filter in which a maximum flux observed at 0.6 bar depleted at 0.7 bar. Therefore, at 0.6 Therefore, at 0.6 bar the possible transition from subcritical flux to limiting flux could begin to trigger the onset of blinding effect or fouling. By conducting filtration at constant pressure, the formation 'cake resistance' resulted in blinding effect that halted filtration of alkaline lysis sample which was also observed at different pressures (Theodossiou et al., 1997). Meanwhile, with PES membrane, a greater flux decline was observed upon TMP increase due to fouling (Arkhangelsky et al., 2011).

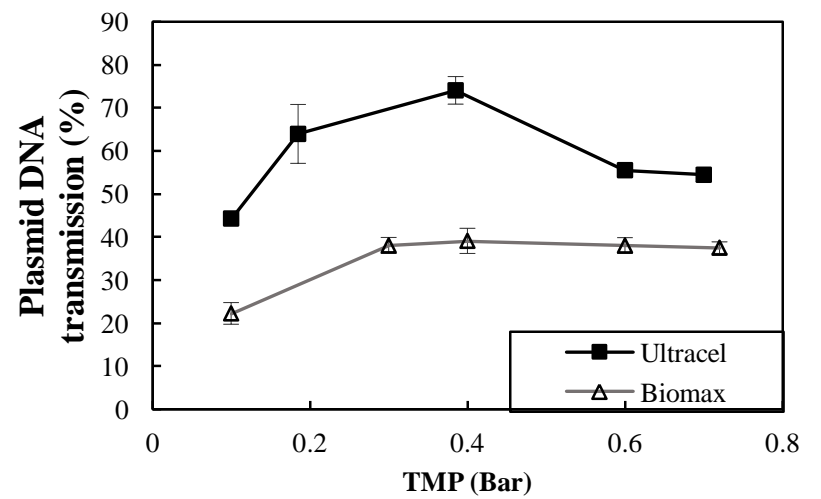

Fig. 3: Plot of plasmid DNA transmission versus transmembrane pressure (TMP) for both Ultracel and Biomax filters.

A plot of plasmid DNA transmission versus TMP was shown in Figure 3. Following TMP increase from 0.1 to 0.2 bar, both filters showed an increment in plasmid DNA transmission. In a work using PES membrane, an increase in plasmid permeation was observed as TMP was increased (Arkhangelsky et al., 2011). At 0.4 bar, Ultracel filter achieved an optimal transmission of $\sim 70 \%$. However, beyond 0.4 bar, plasmid transmission depleted to $55.5 \%$ at 0.6 bar. In contrast with Biomax filter, following a slight increase in TMP from 0.1-0.3 bar, plasmid transmission remained almost constant, even at pressure beyond 0.3 bar. Therefore, throughout all TMPs, greater plasmid transmissions were observed across Ultracel compared to Biomax filter. This observation was also consistent with the higher flow rate and flux observed at each TMP with Ultracel filter. While the plasmid transmission with Ultracel filter was benefited from the higher flow rate and flux, this will be offset by an inherent risk in plasmid quality at higher pressure. At higher TMP, the plasmid DNA could be subjected to lose its integrity related to high flux. For instance, a work using PVDF membrane had shown that the higher flux values generally reduced the plasmid integrity (Kong et al., 2006). A semi logarithmic plot of flux versus DNA plasmid transmission was shown in Figure 4. Using this plot, Latulippe and Zydney measured the sieving coefficient $S$ (equivalent to transmission) for 
plasmid of different topologies and estimated the critical flux value $\left(J_{\text {crit }}\right.$, at sieving $\left.S=0\right)$, i.e., the minimum flux required by plasmid to transfer across membrane (Latulippe and Zydney, 2011). In this plot, $\mathrm{J}_{\text {crit }}$ i.e., the $\mathrm{x}$-axis intercept value was approximately $0.04 \pm 0.01 \mathrm{mLmin}^{-1} \mathrm{~cm}^{-2}$, for the filters. Therefore, given the same $\mathrm{J}_{\text {crit }}$ value, Biomax filters only showed to achieve a lower DNA transmission.

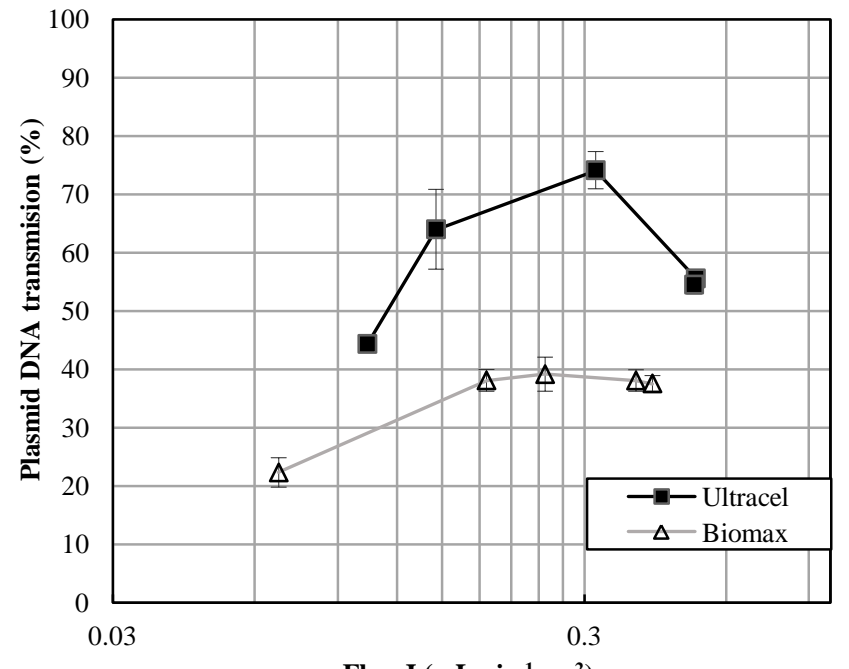

Flux J (mLmin $\left.\mathbf{~}^{-1} \mathbf{c m}^{-2}\right)$

Fig. 4: A semi logarithmic plot of flux versus DNA plasmid transmission for Ultracel and Biomax filters.

In this work, the use of TMP driven by vacuum suction has produced a comparable result with many other works which employed positive pressure in plasmid separation. By comparing these two filters, the difference we observed in DNA transmission was more pronounced than the one that we observed in flux. This fundamental difference was on the fact that regenerated cellulose material is more hydrophilic compared to the hydrophobic nature of polyethersulfone (PES) membrane. By comparing membrane fouling between PES and regenerated cellulose, PES membrane lost up to $75 \%$ of its flux, but regenerated cellulose lost only at $31 \%$ or less (Dosmar and Pinto, 2007). Increase in permeation observed at high TMP was also due to the result of polymer stretching and pore size expansion (Arkhangelsky et al., 2015), and this was enhanced with hydrophilic membrane. The lower permeation observed in PES was commonly attributed to membrane fouling and this was exacerbated by the presence of protein in the lysis sample (Jens Haberkamp et al., 2008; Truskey et al., 1987). Meanwhile, the superiority of regenerated cellulose membrane was also demonstrated in works using other molecules. For instance, in working with protein and lipid samples, Dumay and co-workers reported that $10 \mathrm{kDa}$ regenerated cellulose filters gave a better performance compared to other types of filter (Dumay et al., 2008).

\section{CONCLUSIONS}

In this work, by using pressures generated by vacuum suction, the performances of two ultrafilters made up from different materials were compared. With the TMP range employed, a rather different permeation of plasmid DNA were observed. In general, regenerated cellulose (Ultracel) filter showed to have a higher DNA transmission compared to polyethersulfone PES (Biomax) filter. However, in case of regenerated cellulose, a slight drop in flow rate or flux observed at a very high TMP resulted in a drop in DNA permeation. It is anticipated that the different in performance of these filters were due to the hydrophilicity or hydrophobicity of membrane material. Therefore, the higher plasmid transmission in regenerated cellulose could compromise with subsequent fouling and potential loss in plasmid integrity which may occur at high TMP. This study could also provide a useful guideline in selecting a suitable ultrafiltration membrane for plasmid separation based on hydrophobicity of the material.

\section{ACKNOWLEDGMENTS}

The authors wish to thank Dr Adam Leow Thean Chor, Department of Cell and Molecular Biology, Faculty of Biotechnology and Biomolecular Science, University Putra Malaysia for the providing the strain and vectors used in this work.

Financial support and sponsorship: Ministry of Higher Education (MOHE) Malaysia for enabling this work to be completed under Research Grant RAGS 13-005-0068.

Conflict of Interests: There are no conflicts of interest.

\section{REFERENCES}

Ager K, Latulippe DR, Zydney AL. Plasmid DNA transmission through charged ultrafiltration membranes. Journal of Membrane Science, 2009; 344: 123-28.

Arkhangelsky E, Levitsky I, Gitis V. Retention of Biopolymers by Ultrafiltration Membranes. Chemical Engineering \& Technology, 2015; 38: 2327-34.

Arkhangelsky E, Sefi Y, Hajaj B, Rothenberg G, Gitis V. Kinetics and mechanism of plasmid DNA penetration through nanopores. Journal of Membrane Science, 2011; 371: 45-51.

Bimboim H, Doly J. A rapid alkaline extraction procedure for screening recombinant plasmid DNA. Nucleic acids research, 1979; 7: 1513-23.

Claudia Muro, Riera F, Díaz MdC. 2012. Membrane Separation Process in Wastewater Treatment of Food Industry In Food Industrial Processes - Methods and Equipment, ed. B Valdez, pp. 253-80: InTech, Croatia

Dosmar M, Pinto S. 2007. Crossflow filtration In Filtration and Purification in the Biopharmaceutical Industry, Second Edition, ed. THM Maik W Jornitz pp. Page 495-517 CRC Press

Dumay J, Radier S, Barnathan G, Bergé JP, Jaouen P. Recovery of valuable soluble compounds from washing waters generated during small fatty pelagic surimi processing by membrane processes. Environmental Technology, 2008; 29: 451-61.

Ferreira GNM, Monteiro GA, Prazeres DMF, Cabral JMS Downstream processing of plasmid DNA for gene therapy and DNA vaccine applications. Trends in Biotechnology, 2000; 18: 380-88.

Guerrero-Germán P, Prazeres DM, Guzmán R, MontesinosCisneros RM, Tejeda-Mansir A. Purification of plasmid DNA using tangential flow filtration and tandem anion-exchange membrane chromatography. Bioprocess and biosystems engineering, 2009; 32: $615-$ 23. 
Jens Haberkamp, Mathias Ernst, Gladys Makdissy, Peter M. Huck, Jeke M. Protein fouling of ultrafiltration membranes investigation of several factors relevant for tertiary wastewater treatment. Journal of Environmental Engineering and Science, 2008; 7: 651-60.

Kabsch-Korbutowicz M, Majewska-Nowak K, Winnicki T. Analysis of membrane fouling in the treatment of water solutions containing humic acids and mineral salts. Desalination, 1999; 126: 17985 .

Kong S, Titchener-Hooker N, Levy MS. Plasmid DNA processing for gene therapy and vaccination: Studies on the membrane sterilisation filtration step. Journal of Membrane Science, 2006; 280: 82431 .

Latulippe DR, Zydney AL. Separation of plasmid DNA isoforms by highly converging flow through small membrane pores. Journal of Colloid and Interface Science, 2011; 357: 548-53.

Manzano I, Guerrero-German P, Montesinos-Cisneros RM, Tejeda-Mansir A. Plasmid DNA pre-purification by tangential flow filtration. Biotechnology \& Biotechnological Equipment, 2015; 29: 58691.

Meireles M, Lavoute E, Bacchin P. Filtration of a bacterial fermentation broth: harvest conditions effects on cake hydraulic resistance. Bioprocess and biosystems engineering, 2003; 25: 309-14.
Ramamoorth M, Narvekar A. Non Viral Vectors in Gene Therapy- An Overview. Journal of Clinical and Diagnostic Research : JCDR, 2015; 9: GE01-GE06.

Theodossiou I, Collins IJ, Ward JM, Thomas ORT, Dunnill P. The processing of a plasmid-based gene from $E$. Coli. Primary recovery by filtration. Bioprocess Engineering, 1997; 16: 175-83.

Truskey GA, Gabler R, DiLeo A, Manter T. The effect of membrane filtration upon protein conformation. Journal Parenteral Science \& Technology, 1987; 41: 180-93.

Yin H, Kanasty RL, Eltoukhy AA, Vegas AJ, Dorkin JR, Anderson DG. Non-viral vectors for gene-based therapy. Nature Review Genetics, 2014; 15: 541-55.

\section{How to cite this article:}

Mostafa SW, El-Sersy NA, Abdelwahab AE, Ali MAR. Statistical optimization and valuable applications of bioactive compounds produced by marine Pseudoalteromonas piscicida. J App Pharm Sci, 2017; 7 (07): 046-050. 